\title{
Distribution of the number of scientific and pedagogical staff of universities by work experience
}

\author{
Distribuição do número de quadros científicos e pedagógicos de \\ universidades por experiência de trabalho
}

\section{Distribución del número de personal científico y pedagógico de las universidades por antigüedad}

\author{
Iuliia S. Pinkovetskaia1 ${ }^{\text {iD }}$ \\ ${ }^{1}$ Ulyanovsk State University, Ulyanovsk, Russia. \\ Corresponding author: \\ Iuliia S. Pinkovetskaia \\ Email: pinkovetskaia@gmail.com \\ How to cite: Pinkovetskaia, I. S. (2022). Distribution of the number of scientific and pedagogical staff of universities by \\ work experience. Revista Tempos e Espaços em Educação, 15(34), e17010. \\ http://dx.doi.org/10.20952/revtee.v15i34.17010
}

\begin{abstract}
The purpose of our study was to assess the proportion of teachers with different work experience in relevant positions in higher education institutions in the total number of university teachers in each of the regions of Russia. In the course of the work, the indicators characterizing the proportion of teachers belonging to five groups by work experience of up to five years, from five to ten years, from ten to fifteen years, from fifteen to twenty years and more than twenty years in the total number of teachers working in higher educational institutions were evaluated. The study used official statistical information for 82 regions of Russia. We used the density functions of the normal distribution as models. The results of the study allowed us to draw conclusions: approximately every fourteenth teacher has worked in a teaching position for less than five years, every ninth teacher has worked in this position for five to ten years, every seventh teacher has worked in this position for ten to fifteen years, every fifth teacher has worked in this position for fifteen to twenty years. It is proved that the number of teachers with work experience up to twenty years was $52 \%$ and was slightly more than the number of teachers with work experience of more than twenty years (48\%). The analysis showed the presence of a certain differentiation of the values of the considered indicators by region. The proposed methodological approach and the results obtained have originality and scientific novelty.

Keywords: Functions of normal distribution. Higher education. Regions of Russia. University teachers.
\end{abstract}




\section{RESUMO}

O objetivo do nosso estudo foi avaliar a proporção de professores com experiência de trabalho diferente em cargos relevantes em instituições de ensino superior no número total de professores universitários em cada uma das regiões da Rússia. No decorrer do trabalho, os indicadores que caracterizam a proporção de professores pertencentes a cinco grupos de experiência de trabalho de até cinco anos, de cinco a dez anos, de dez a quinze anos, de quinze a vinte anos e mais de vinte anos no número total de professores que trabalham em instituições de ensino superior foram avaliados. $O$ estudo utilizou informações estatísticas oficiais para 82 regiões da Rússia. Usamos as funções de densidade da distribuição normal como modelos. Os resultados do estudo permitiramnos tirar conclusões: aproximadamente a cada catorze professor trabalhou em uma posição de professor para menos de cinco anos, cada nono professor tem trabalhado nesta posição por cinco a dez anos, a cada sétimo professor tem trabalhado nesta posição por dez a quinze anos, uma em cada cinco professores tem trabalhado nesta posição por mais de quinze a vinte anos. Está provado que o número de professores com experiência de trabalho até vinte anos foi de $52 \%$ e foi ligeiramente superior ao número de professores com experiência de trabalho superior a vinte anos (48\%). A análise mostrou a presença de uma certa diferenciação dos valores dos indicadores considerados por região. A abordagem metodológica proposta e os resultados obtidos têm originalidade e novidade científica.

Palavras-chave: Ensino superior. Funções de distribuição normal. Professor. Regiões da Rússia.

\section{RESUMEN}

El objetivo de nuestro estudio fue evaluar la proporción de profesores con experiencia laboral diferente en puestos relevantes en instituciones de educación superior en el número total de profesores universitarios en cada una de las regiones de Rusia. En el curso del trabajo, se evaluaron los indicadores que caracterizan la proporción de docentes pertenecientes a cinco grupos por experiencia laboral de hasta cinco años, de cinco a diez años, de diez a quince años, de quince a veinte años y más de veinte años en el número total de docentes que trabajan en instituciones de educación superior. El estudio utilizó información estadística oficial de 82 regiones de Rusia. Utilizamos las funciones de densidad de la distribución normal como modelos. Los resultados del estudio nos permitieron sacar conclusiones: aproximadamente cada decimocuarto maestro ha trabajado en un puesto de enseñanza por menos de cinco años, cada noveno maestro ha trabajado en este puesto por cinco a diez años, cada séptimo maestro ha trabajado en este puesto por diez a quince años, cada quinto maestro ha trabajado en este puesto por quince a veinte años. Se ha demostrado que el número de profesores con experiencia laboral de hasta veinte años era del 52\% y era ligeramente superior al número de profesores con experiencia laboral de más de veinte años (48\%). El análisis mostró la presencia de una cierta diferenciación de los valores de los indicadores considerados por región. El enfoque metodológico propuesto y los resultados obtenidos tienen originalidad y novedad científica.

Palabras clave: Educación superior. Funciones de distribución normal. Profesores universitarios. Regiones de Rusia.

\section{INTRODUCTION}

At the end of the twentieth and the beginning of the twenty-first century, in the vast majority of countries, increased attention was paid to the development of higher education (Mense et al., 2018; Jung Cheol Shin, 2012; Li, 2021). For the development of the higher education system, it is necessary to solve such a problem as the constant replenishment of qualified scientific and pedagogical staff of universities. Teachers at institutes of higher education teach students by transferring to them a significant amount of new knowledge, skills, competencies (Mokyr, 2002). Taking this into account, one of the urgent scientific problems is the assessment of indicators 
characterizing the distribution of the number of teachers of higher education institutions by their experience. Our research was devoted to this issue. Studying the current level of solving this problem is important both for state bodies regulating activities in this area and directly for universities (Marginson, 2006; Barnett, 2017). In addition, the problem under consideration has a certain interest for people who would like to continue their careers as teachers (Knight, Yorke, 2003).

Despite the existence of extensive research on the problem of the development of higher education, so far not enough attention has been paid to the regional specifics of solving this problem. At the same time, in recent years, according to the authors of a number of scientific publications (for example, Cervantes, 2017; Unger, Polt, 2017) there has been an increased interest in the study of regional aspects of the development of higher education. Our article responds to the relevant appeals and is devoted to the study of the existing differentiation of the number of scientific and pedagogical personnel of higher education systems by region.

Currently, the system of higher education in Russia has been greatly developed. The total number of universities and other specialized in teaching students under bachelor's, specialist's and master's degree programs amounted to 1,259 independent organizations and branches in 2020. These institutes of higher education employed 223088 people holding scientific and pedagogical positions. Of these, 35039 served as professors and 129328 as associate professors (Official statistical information, 2021).

The purpose of our study was to assess the proportion of teachers with different work experience in relevant positions in higher education organizations in the total number of university teachers in each of the regions of Russia. Our article was devoted to obtaining new knowledge about the distribution of scientific and pedagogical personnel employed in the higher education systems of the regions by pedagogical experience. The contribution of the article to the information on the problem under consideration consisted in the author's method of modeling the distribution by length of service of the number of professors and teachers at universities and other higher educational institutions of the regions of Russia. The empirical contribution is related to the determination of averages and standard deviations by region of indicators characterizing the share of teachers with different work experience in their total number in the regions under consideration. In addition, the regions in which the minimum and maximum values of these indicators were noted in 2020 were identified.

The structure of this work included the following sections. The second section provides a brief overview of scientific publications on the problem of the peculiarities of teaching activities of academic staff with different experience of relevant work. The third section provides the methodology, initial data and design of the study. The fourth section demonstrates the results of modeling the initial empirical data, as well as the results of testing the quality of the developed models. The fifth section discusses the results of the study. The last sections contain conclusions and bibliographic references.

\section{LITERATURE REVIEW}

The problem of assessing such an aspect of the development of higher education as the distribution of the number of teachers by their work experience (length of service) has been reflected in a number of scientific publications. A brief description of the most interesting of them is given in table 1. 
Table 1. Scientific publications on the peculiarities of the structure of university teachers by work experience.

\begin{tabular}{cc}
\hline Authors & Problems under study \\
\hline 1 & 2 \\
\hline
\end{tabular}

The features of professional training of university teachers at the initial

Alles et al. (2019) stages of their activities are considered. The information on the results of a survey of 537 teachers in Germany was studied. their careers. The expediency of combining the improvement of teaching qualifications and conducting scientific research is shown.

The influence of the level of education and the subject area on the activity of teachers, especially at the beginning of work, is studied. It is shown that with the accumulation of experience, prerequisites for successful career

King Rice (2013) development are created. The importance of implementing policy measures aimed at improving the remuneration of teachers, their support and professional development is emphasized.

The problem of improving the educational policy aimed at improving the competencies and skills of university teachers to ensure competitive

Vasquez-Martinez et al. (2013)

Volchik et al. (2019)

Graham (2018)

Graham (2020)

Bogdanova et al. (2018)

Pugach (2017)

Karpovich, Voronova (2020) advantages is considered. The research is based on the study of various variants of educational models implemented in the context of economic globalization.

The analysis of the structure of the scientific and pedagogical staff of higher education organizations in Russia in 1980-2017 is presented.

The book demonstrates two options for the development of academic careers of university employees: teaching and research.

The conclusion is made about the importance of both options for improving the effectiveness of educational activities. The system of promotion of university teachers in the process of increasing their work experience is proposed.

The analysis of the influence of the experience of university teachers on the quality of their activities is given. It is proved that the quality of teaching does not decrease with an increase in work experience.

The features of the teaching staff, depending on the length of service, are studied.

The analysis of the current structure of the number of teachers of higher education institutions in Russia for 1988-2014 is given.

The assessment of the professional training of novice university teachers is given and the problems associated with the motivation of their adaptation to work as teachers are identified.

Source: the table is compiled by the author on the basis of the information provided in the RSCl.

Based on the information given in table 1, it can be stated that the problem of research on the distribution of the number of teachers by their work experience in the higher education system is relevant. At the same time, some scientific studies have concluded that there are regional features characteristic of individual territorial entities. Taking this into account, it seems appropriate to conduct a comparative analysis of the existing specific indicators of the distribution of the number of university teachers based on their work experience in different regions of Russia.

\section{METHODOLOGY}

Our paper examines the distribution of academic staff of higher education organizations, based on teaching experience. At the same time, university teachers who taught students in 2020 
in Russia under bachelor's degree programs (four years of study), specialty (five years of study), as well as master's degree programs are considered.

The research process included five stages. At the first stage, the initial data describing the total number of teachers working in the higher education systems of each of the regions of Russia, as well as the number of teachers included in the five main groups, depending on their work experience, were formed. The first group included teachers who have held relevant positions for less than five years, the second group - from five to ten years, the third group - from ten to fifteen years, the fourth group - from fifteen to twenty years and the fifth group - more than fifteen years. At the second stage, indicators describing the share of teachers belonging to each of the five groups in the total number of university teachers located in each of the regions of Russia were calculated. At the third stage, the distribution of indicators by region was estimated based on the development of mathematical models. At the fourth stage, the average values of indicators for the regions of Russia were determined, as well as the ranges in which the values of these indicators are for most of them. At the fifth stage, the regions in which the maximum and minimum values of indicators were noted were determined.

The study used official statistical information of the Ministry of Science and Higher Education of the Russian Federation for 2020 on the number of teachers working in higher education institutions in 82 regions of Russia (Official statistical information, 2021).

In our study, three hypotheses were tested:

- hypothesis 1: the share of university teachers in their total number increases with the increase in the length of service as teachers;

- hypothesis 2: the values of the five indicators under consideration have a significant differentiation between different regions;

- hypothesis 3: regions that are characterized by the maximum and minimum values of each of the five indicators have a different geographical location among the federal districts.

The evaluation of the values of the five considered indicators was carried out on the basis of economic and mathematical modeling of the initial empirical data. As models, we used the density functions of the normal distribution, the method of developing which for estimating the values of specific indicators was proposed by the author. Some aspects of the use of the methodology are given in the works (Pinkovetskaya et al., 2021; Pinkovetskaia, 2021). During the development of the functions, the initial empirical data were grouped according to the ranges of changes in the values of the indicators. These data groups can be geometrically represented as corresponding histograms. Data approximation using normal distribution functions was carried out using generally accepted statistical methods. It is important to note that the average values of the considered indicators, as well as their standard deviations for the density functions of the normal distribution, were displayed in the formulas of the developed functions themselves. Therefore, by constructing a specific function, we obtain the specified parameters of the indicators under consideration without additional calculations.

The obtained functions allowed us to determine the average values of each of the five indicators for the regions under consideration, as well as the ranges of their changes characteristic of most regions. In addition, the study identified regions in which the considered indicators have values above the upper and below the lower limits of the ranges. The boundaries of the indicator ranges for $68 \%$ of the regions were determined based on the average values of the indicators and the corresponding standard deviations.

\section{RESULTS}

In the course of the computational experiment, economic and mathematical modeling was carried out on the basis of empirical data. The models that describe the distributions $\left(y_{1}, y_{2}, y_{3}\right.$ 
$\left., y_{4}, y_{5}\right)$ of the three indicators $\left(x_{1}, \% ; x_{2}, \% ; x_{3}, \% ; x_{4}, \% ; x_{5}, \%\right)$ across all 82 Russian regions are shown below:

- the share of university teachers, working in this sphere less than five years in 2020 in the total number of faculty staff

$$
y_{1}\left(x_{1}\right)=\frac{160.00}{2.42 \times \sqrt{2 \pi}} \cdot e^{-\frac{\left(x_{1}-7.16\right)^{2}}{2 \times 2.42 \times 2.42}}
$$

- the share of university teachers, working in this sphere from five to ten years in 2020 in the total number of faculty staff

$$
y_{2}\left(x_{2}\right)=\frac{210.00}{2.89 \times \sqrt{2 \pi}} \cdot e^{-\frac{\left(x_{2}-10.78\right)^{2}}{2 \times 2.89 \times 2.89}} ;
$$

- the share of university teachers, working in this sphere from ten to fifteen years in 2020 in the total number of faculty staff

$$
y_{3}\left(x_{3}\right)=\frac{240.00}{2.70 \times \sqrt{2 \pi}} \cdot e^{-\frac{\left(x_{3}-14.45\right)^{2}}{2 \times 2.70 \times 2.70}}
$$

- the share of university teachers, working in this sphere from fifteen to twenty years in 2020 in the total number of faculty staff

$$
y_{4}\left(x_{4}\right)=\frac{240.00}{3.21 \times \sqrt{2 \pi}} \cdot e^{-\frac{\left(x_{4}-19.17\right)^{2}}{2 \times 3.21 \times 3.21}}
$$

- the share of university teachers, working in this sphere more than twenty years in 2020 in the total number of faculty staff

$$
y_{5}\left(x_{5}\right)=\frac{550.00}{7.13 \times \sqrt{2 \pi}} \cdot e^{-\frac{\left(x_{5}-48.05\right)^{2}}{2 \times 7.13 \times 7.13}}
$$

\begin{tabular}{|c|c|c|c|}
\hline \multirow[b]{2}{*}{ Indicators } & \multicolumn{3}{|c|}{ Criteria } \\
\hline & $\begin{array}{l}\text { The } \\
\text { Kolmogorov- } \\
\text { Smirnov test }\end{array}$ & $\begin{array}{c}\text { The Pearson } \\
\text { test }\end{array}$ & $\begin{array}{c}\text { The Shapiro- } \\
\text { Wilk test }\end{array}$ \\
\hline $\begin{array}{l}\text { The share of university teachers, working in this } \\
\text { sphere less than five years in } 2020 \text { in the total number } \\
\text { of faculty staff }\end{array}$ & 0.05 & 1.41 & 0.97 \\
\hline $\begin{array}{c}\text { The share of university teachers, working in this } \\
\text { sphere from five to ten years in } 2020 \text { in the total } \\
\text { number of faculty staff }\end{array}$ & 0.03 & 1.13 & 0.98 \\
\hline $\begin{array}{c}\text { The share of university teachers, working in this } \\
\text { sphere from ten to fifteen years in } 2020 \text { in the total } \\
\text { number of faculty staff }\end{array}$ & 0.04 & 2.86 & 0.96 \\
\hline $\begin{array}{l}\text { The share of university teachers, working in this } \\
\text { sphere from fifteen to twenty years in } 2020 \text { in the } \\
\text { total number of faculty staff }\end{array}$ & 0.03 & 0.52 & 0.98 \\
\hline $\begin{array}{c}\text { The share of university teachers, working in this } \\
\text { sphere more than twenty years in } 2020 \text { in the total } \\
\text { number of faculty staff }\end{array}$ & 0.05 & 1.81 & 0.97 \\
\hline
\end{tabular}

The quality of functions (1)-(5) we tested using such criteria: by the Kolmogorov-Smirnov, the Pearson and the Shapiro-Wilk. Calculated values of criteria are given in table 2.

Table 2. Calculated values of criteria. 
Information given in column 2 of table 2 showed that all calculated values are less than the critical value by the Kolmogorov-Smirnov test (0.174) at significant level equal 0.05. Data in column 3 are less than critical value of Pearson criterion (9.49). Data in column 4 exceed critical value 0.93 Shapiro-Wilk test with significant level of 0.01 . Thus, the computational experiment showed that all nine developed functions have high quality.

Based on the developed functions (1)-(5), the average values of indicators characterizing the distribution of the number of university teachers by work experience in the higher education system were determined for the regions of Russia. These values are given in the second column of table 3 . The third column of this table shows the standard deviations for each of the five indicators. The values of the indicators characterizing the upper and lower boundaries of the intervals corresponding to most regions are given in the fourth column. We calculate the lower bound of the interval as the difference between the mean and the standard deviation. Accordingly, the upper bound is calculated as the sum of the mean and standard deviation.

Table 3. Values of indicators characterizing distribution of university teachers' number by work experience in the higher education system in the regions of Russia in $2020, \%$.

\begin{tabular}{|c|c|c|c|}
\hline Indicator numbers & Average values & Standard deviation & $\begin{array}{l}\text { Values for most } \\
\text { regions }\end{array}$ \\
\hline 1 & 2 & 3 & 4 \\
\hline $\begin{array}{l}\text { The share of university teachers, working in } \\
\text { this sphere less than five years in } 2020 \text { in the } \\
\text { total number of faculty staff }\end{array}$ & 7.16 & 2.42 & $4.74-9.58$ \\
\hline $\begin{array}{l}\text { The share of university teachers, working in } \\
\text { this sphere from five to ten years in } 2020 \text { in the } \\
\text { total number of faculty staff }\end{array}$ & 10.78 & 2.89 & 7.89-13.67 \\
\hline $\begin{array}{l}\text { The share of university teachers, working in } \\
\text { this sphere from ten to fifteen years in } 2020 \text { in } \\
\text { the total number of faculty staff }\end{array}$ & 14.45 & 2.70 & $11.75-17.15$ \\
\hline $\begin{array}{l}\text { The share of university teachers, working in } \\
\text { this sphere from fifteen to twenty years in } \\
2020 \text { in the total number of faculty staff }\end{array}$ & 19.17 & 3.21 & $15.96-22.38$ \\
\hline $\begin{array}{c}\text { The share of university teachers, working in } \\
\text { this sphere more than twenty years in } 2020 \text { in } \\
\text { the total number of faculty staff }\end{array}$ & 48.05 & 7.13 & $40.92-55.18$ \\
\hline
\end{tabular}

Source: the calculations are carried out by the author on the basis of functions (1)-(5).

\section{DISCUSSION}

The average value for Russian regions of the share of university teachers working in this sphere less than five years in the total number of faculty staff is $7.2 \%$. That is, approximately every fourteenth teacher has worked in this position for less than five years. The values of this indicator for most regions range from $4.7 \%$ to $9.6 \%$.

The average value for Russian regions of the share of university teachers working in this sphere from ten to fifteen years in the total number of faculty staff was $10.8 \%$. That is, approximately every ninth teacher has worked in this position for five to ten years. The values of this indicator, typical for most regions, ranged from $7.9 \%$ to $13.7 \%$.

The average value for the Russian regions of the share of university teachers working in this sphere from ten to fifteen years in the total number of faculty staff was $14.5 \%$. That is, approximately every seventh teacher has worked in this position for ten to fifteen years. The values of this indicator, typical for most regions, ranged from $11.7 \%$ to $17.2 \%$. 
The average value for the Russian regions of the share of university teachers working in this sphere from fifteen to twenty years in the total number of faculty staff was $19.2 \%$. That is, approximately every fifth teacher has worked in this position for fifteen to twenty years. The values of this indicator, typical for most regions, ranged from $15.9 \%$ to $22.4 \%$.

The analysis of the average values of the four indicators discussed above allowed us to conclude that these values showed stable growth with an increase in the length of service as university teachers. The average proportion of teachers with small work experience (less than five years) was 2.7 times less than teachers with significant work experience at universities (from fifteen to twenty years). Thus, the first hypothesis that the share of university teachers in their total number increases with a growth in the length of service as teachers has been confirmed.

The average value for the Russian regions of the share of university teachers working in this sphere more than twenty years in 2020 in the total number of faculty staff was slightly more than $48 \%$. That is, approximately every second teacher has worked in this position for more than twenty years. The values of this indicator, typical for most regions, ranged from $40.9 \%$ to $55.2 \%$.

It is interesting to note that in 2020 in the regions of Russia the number of teachers with work experience up to twenty years was $52 \%$ and was slightly more than the number of teachers with work experience of more than twenty years $(48 \%)$. There was a similar trend in the regions of Russia. In 43 regions the share of teachers of the first group exceeded the share of teachers of the second group, in 12 regions the numbers for these two groups practically coincided. And in 27 regions, the number of teachers with more than twenty years of experience exceeded the number of teachers with less than twenty years of experience.

To test hypothesis 2 on the differentiation of indicators by region, an analysis of the degree of variation of each of the indicators presented in table 3 was carried out. To do this, we used the standard deviations indicated in column 3 . The variation indices are as follows: for the first indicator - $34 \%$, for the second indicator $-27 \%$, for the third indicator $-19 \%$, for the fourth indicator $-17 \%$, the fifth indicator $-15 \%$. This analysis showed a significant (more than $33 \%$ ) differentiation of the value only by the first indicator. In other indicators, the differentiation was less significant. That is, the second hypothesis was partially confirmed.

The next step was to identify the Russian regions where the maximum and minimum values of each indicator were noted. In this case, the maximum values are those that exceed the upper limits of the ranges specified in column 4 of table 3 , and the minimum values are those that are less than the lower limits of the specified ranges. The results of this analysis are shown in table 4. Along with the lists of regions, this table also provides values of indicators on regions and geographical location of regions.

Table 4. Characteristics of Russian regions with maximum and minimum indicator values.

\begin{tabular}{cccc}
\hline Indicators & Region & Value,\% & Federal district \\
\hline 1 & 2 & 3 & 4 \\
\hline & With maximum values of indicators & \\
\cline { 2 - 4 } & Astrakhan region & 9.9 & South \\
Kamchatka territory & 10.1 & Far East \\
the share of university & Moscow region & 10.5 & Central \\
teachers, working in this & Tatarstan republic & 10.5 & Privolzskiy \\
sphere less than five years & Moscow city & 10.9 & Central \\
in 2020 in the total & St. Petersburg city & 11.1 & North-West \\
number of faculty staff & Oryol region & 11.2 & Central \\
& Ulyanovsk region & 11.8 & Privolzskiy \\
& Ryazan region & 12.0 & Central \\
& Tyva republic & 12.9 & Cemtral \\
& Chechen republic & 13.4 & North-Caucasian \\
\hline
\end{tabular}




\begin{tabular}{|c|c|c|c|}
\hline & \multicolumn{3}{|c|}{ With minimum values of indicators } \\
\hline & Sakhalin region & 0.7 & Far East \\
\hline & Kurgan region & 1.5 & Ural \\
\hline & Novgorod region & 3.3 & North-West \\
\hline & Kostroma region & 3.5 & Central \\
\hline & Khakassia republic & 3.6 & Siberian \\
\hline & Adygea republic & 3.6 & North-Caucasian \\
\hline & Vologda region & 3.7 & North-West \\
\hline & Bryansk region & 4.0 & Central \\
\hline & Lipetsk region & 4.2 & Central \\
\hline & Murmansk region & 4.2 & North-West \\
\hline & Karelia republic & 4.5 & North-West \\
\hline \multirow{21}{*}{$\begin{array}{l}\text { the share of university } \\
\text { teachers, working in this } \\
\text { sphere from five to ten } \\
\text { years in } 2020 \text { in the total } \\
\text { number of faculty staff }\end{array}$} & \multicolumn{3}{|c|}{ With maximum values of indicators } \\
\hline & Perm region & 14.3 & Privolzskiy \\
\hline & Pskov region & 14.5 & North-West \\
\hline & Trans-Baikal territory & 14.5 & Far East \\
\hline & Stavropol territory & 14.6 & South \\
\hline & Bashkortostan republic & 14.6 & Privolzskiy \\
\hline & Tatarstan republic & 15.1 & Privolzskiy \\
\hline & Ingushetia republic & 16.3 & North-Caucasian \\
\hline & Crimea republic & 19.6 & South \\
\hline & Oryol region & 20.7 & Central \\
\hline & \multicolumn{3}{|c|}{ With minimum values of indicators } \\
\hline & Altai republic & 4.2 & Siberian \\
\hline & Khakassia republic & 5.4 & Siberian \\
\hline & Novgorod region & 5.9 & North-West \\
\hline & Vologda region & 6.1 & North-West \\
\hline & Kamchatka territory & 6.3 & Far East \\
\hline & Murmansk region & 6.7 & North-West \\
\hline & Amur region & 6.7 & Far East \\
\hline & Bryansk region & 6.9 & Central \\
\hline & Adygea republic & 7.2 & North-Caucasian \\
\hline & Kaliningrad region & 7.4 & North-West \\
\hline \multirow{17}{*}{$\begin{array}{l}\text { the share of university } \\
\text { teachers, working in this } \\
\text { sphere from ten to fifteen } \\
\text { years in } 2020 \text { in the total } \\
\text { number of faculty staff }\end{array}$} & \multicolumn{3}{|c|}{ With maximum values of indicators } \\
\hline & Trans-Baikal territory & 18.1 & Far East \\
\hline & Belgorod region & 18.6 & Central \\
\hline & Perm region & 19.2 & Privolzskiy \\
\hline & Ingushetia republic & 21.3 & North-Caucasian \\
\hline & Oryol region & 27.9 & Central \\
\hline & \multicolumn{3}{|c|}{ With minimum values of indicators } \\
\hline & Magadan region & 8.8 & Far East \\
\hline & Sevastopol city & 9.1 & South \\
\hline & Mordovia republic & 9.8 & Privolzskiy \\
\hline & Novgorod region & 10.3 & North-West \\
\hline & Khakassia republic & 10.6 & Siberian \\
\hline & Sakhalin region & 11.2 & Far East \\
\hline & Kamchatka territory & 11.4 & Far East \\
\hline & Tyva republic & 11.5 & Central \\
\hline & Crimea republic & 11.6 & South \\
\hline & Murmansk region & 11.7 & North-West \\
\hline
\end{tabular}




\begin{tabular}{|c|c|c|c|}
\hline & With maxim & f indica & \\
\hline & Karachay-Cherkess republic & 23.2 & North-Caucasian \\
\hline & Lipetsk region & 23.3 & Central \\
\hline & Orenburg region & 23.6 & South \\
\hline & Tyva republic & 23.7 & Siberian \\
\hline & Kurgan region & 24.3 & Ural \\
\hline & Kamchatka territory & 25.3 & Far East \\
\hline & Bryansk region & 25.8 & Central \\
\hline & Trans-Baikal territory & 25.8 & Far East \\
\hline the share of university & Ingushetia republic & 26.9 & North-Caucasian \\
\hline teachers, working in this & Sevastopol city & 30.5 & South \\
\hline $\begin{array}{l}\text { sphere from fifteen to } \\
\text { twenty vears in } 2020 \text { in the }\end{array}$ & With minim & indica & \\
\hline total number of faculty & Novgorod region & 13.4 & North-West \\
\hline staff & Sakha republic & 13.9 & Far East \\
\hline & Khabarovsk territory & 14.4 & Far East \\
\hline & Crimea republic & 14.5 & South \\
\hline & Primorsky territory & 14.7 & Far East \\
\hline & Moscow city & 14.9 & Central \\
\hline & North Ossetia republic & 14.9 & North-Caucasian \\
\hline & Kaliningrad region & 15.4 & North-West \\
\hline & Ivanovo region & 15.6 & Central \\
\hline & Ryazan region & 15.6 & Central \\
\hline & Tver region & 15.6 & Central \\
\hline & With maxim & indica & \\
\hline & Oryol region & 24.3 & Central \\
\hline & Ingushetia republic & 27.9 & North-Caucasian \\
\hline & Trans-Baikal territory & 34.7 & Far East \\
\hline & Chechen republic & 34.8 & North-Caucasian \\
\hline & Perm region & 36.0 & Privolzskiy \\
\hline & Tatarstan republic & 37.0 & Privolzskiy \\
\hline & Ulyanovsk region & 37.0 & Privolzskiy \\
\hline & Stavropol territory & 40.3 & North-Caucasian \\
\hline the share of university & Belgorod region & 40.7 & Central \\
\hline teachers, working in this & With minim & indica & \\
\hline spnere more than twenty & Sakha republic & 55.5 & Far East \\
\hline number of faculty staff & Ivanovo region & 55.7 & Central \\
\hline & Kostroma region & 55.7 & Central \\
\hline & Altai republic & 55.8 & Ural \\
\hline & Magadan region & 56.9 & Far East \\
\hline & Kaliningrad region & 57.5 & North-West \\
\hline & Vologda region & 58.5 & North-West \\
\hline & Murmansk region & 58.7 & North-West \\
\hline & Khakassia republic & 63.2 & Siberian \\
\hline & Sakhalin region & 63.2 & Far East \\
\hline & Novgorod region & 66.4 & North-West \\
\hline
\end{tabular}

Source: developed by the author on the basis of data from table 3 .

Table 4 provides information on the geographical location of regions (column 3), i.e. to which of federal districts in Russia they devote (column 4). The analysis of this information showed that there is no relationship between the maximum and minimum values of indicators and the territorial location of regions. That is, regions with high and low values of indicators are located in different federal districts. Thus, we can state the confirmation of the third hypothesis. 


\section{CONCLUSION}

The purpose of our study related to the assessment of the share of teachers with different work experience in relevant positions in higher education organizations in the total number of university teachers in each of the regions of Russia has been achieved. The following conclusions have scientific novelty and originality. Firstly, a methodology was proposed for evaluating indicators characterizing the distribution of the total number of university teachers by work experience in the higher education system, using the density functions of the normal distribution. Five groups of teachers formed on this basis were considered. The proposed methodology gave opportunity for making distribution of relevant indicators across all 82 regions of Russia. The results of the development of normal distribution density functions showed that approximately every fourteenth teacher has worked in a teaching position for less than five years, every ninth teacher has worked in this position for five to ten years, every seventh teacher has worked in this position for ten to fifteen years, every fifth teacher has worked in this position for fifteen to twenty years. It is proved that the number of teachers with work experience up to twenty years was $52 \%$ and was slightly more than the number of teachers with work experience of more than twenty years $(48 \%)$.

The analysis showed the presence of a certain differentiation of the values of the considered indicators by region. At the same time, the differentiation was not significant for four of the five indicators.

The regions that were characterized by the maximum and minimum values of each of the five indicators under consideration were identified. The study showed that the geographical location of the regions does not significantly affect the maximum and minimum values of the indicators.

The practical significance of the study for the government is to take into account the existing territorial differences in the experience of teachers in the higher education system. The results of the work can be used in the activities of federal and regional structures related to the support of educational processes, when justifying their planned activities to attract scientific and teaching staff to work in the higher education system. The new knowledge gained is of interest and can be used in the educational process at universities. The study had no limitations, since empirical data of official statistical information for all 82 regions of Russia were considered. Further research may be aimed at establishing the gender structure of the distribution of university teachers with different work experience in the regions of Russia.

Authors' Contributions: Pinkovetskaia, I. S.: conception and design, acquisition of data, analysis and interpretation of data, drafting the article, critical review of important intellectual content. The author has read and approved the final version of the manuscript.

Ethics Approval: Not applicable.

Acknowledgments: Not applicable.

\section{REFERENCES}

Alles, M., Apel, J., Seidel, T., \& Stürmer, K. (2019). How Candidate Teachers Experience Coherence in University Education and Teacher Induction: the Influence of Perceived Professional Preparation at University and Support during Teacher Induction. Vocations and Learning, 12, 87-112. https://doi.org/10.1007/s12186-018-9211-5

Barnett, R. (2017). Constructing the university: Towards a social philosophy of higher education. Education Philosophy Theory, 49(1), 78-88.

Bogdanova, T.M., Since, M.S., Banking, M.A., Demon, A.S., \& Zankina, A.Y. (2018). Psychological personal characteristics of the faculty depending on employment period. International journal of applied and fundamental research, 6, 198-202. 
Cervantes, M. (2017). Higher education institutions in the knowledge triangle. Foresight and STI Governance, 11(2), 27-42.

Graham, L.J., White, S.L.J., Cologon, K., \& Pianta R.C. (2020). Do teachers' years of experience make a difference in the quality of teaching? Teaching and Teacher Education, 96, 103190, 1-10.

Graham, R. (2018). The Career Framework for University Teaching: background and overview. Royal Academy of Engineering Prince Philip House. Carlton House Terrace. London.

Jung Cheol Shin. (2012). Higher education development in Korea: western university ideas, Confucian tradition, and economic development. Higher Education, 64(1), 59-72.

Karpovich, I., \& Voronova, L. (2020). Adaptation of young university teachers with 1-3 years and 3-5 years of work experience. Azimuth of Scientific Research: Pedagogy and Psychology, 9, 2(31), 106-110.

King Rice, J. (2013). Learning from Experience? Evidence on the Impact and Distribution of Teacher Experience and the Implications for Teacher Policy. Education Finance and Policy, 8(3), 332-348. https://doi.org/10.1162/EDFP a 00099

Knight, P.T., \& Yorke, M. (2003). Employability and Good Learning in Higher Education. Teaching in Higher Education, 8:1, 3-16. https://doi.org/10.1080/1356251032000052294

Li, J. (2021). Learner-Centred Learning Tasks in Higher Education: A Study on Perception among. Students Education Science, 11, 230, 1-13. https://doi.org/10.3390/educsci11050230

Marginson, S. (2006). Dynamics of National and Global Competition in Higher Education. Higher Education, 52, 1-39. https://doi.org/10.1007/s10734-004-7649-x

Mense, E.G., Lemoine P., Garretson, C.J., \& Richardson, M.D. (2018). The Development of Global Higher Education in a World of Transformation. Journal of Education and Development, 2(3), 47-60. https://doi.org/10.20849/jed.v2i3.529

Mokyr, J. (2002). The gifts of Athena: Historical origins of the knowledge economy. Princeton University Press. Princeton.

Official statistical information on additional professional and higher education. (2021), Ministry of Science and Higher Education of the Russian Federation. Available at: https://minobrnauki.gov.ru/action/stat/highed/

Pinkovetskaia, I.S. (2021). Territorial features of the development of higher education in Russia. Revista Tempos e Espaços em Educação, 14(33), e16214. http://dx.doi.org/10.20952/revtee.v14i33.16214

Pinkovetskaia, I., Nuretdinova, Y., Nuretdinov, I., \& Lipatova, N. (2021). Mathematical modeling on the base of functions density of normal distribution. Revista de la Universidad Del Zulia, 3a época, Año 12, n. 33.

Pugach, V.F. (2017). The age of teachers in Russian universities: what is the problem? Higher education in Russia, 208(1), 47-55.

Unger, M., \& Polt, W. (2017). The knowledge triangle between research, education and innovation - A conceptual discussion. Foresight-Russia, 2, 10-26.

Vasquez-Martinez, C.-R., Gonzalez-Gonzalez, F.-A., Chavoya-Gama, J.-I., Morfi-Otero, M., Giron, G., Munoz-Macias, H., \& Zuniga-Medina, L.-M. (2013). Work experience in university professors with popularizing their empowerment. Universidad de Guadalajara. Impresos Alfa Puerto Vallarta. Jalisco. Mexico.

Volchik, V., Zhuk, A., Oganesyan, A., \& Abrhám, J. (2019). Analysis of the institutional building and sustainable development of higher education in transition economies. Entrepreneurship and Sustainability Issues, 7(2), 14131423.

Wosnitza, M., Helker, K., \& Lohbeck, L. (2014). Teaching goals of early career university teachers in Germany. International Journal of Educational Research, 65(1), 90-103. http://dx.doi.org/10.1016/i.ijer.2013.09.009

Received: 31 August 2021 | Accepted: 20 October 2021 | Published: 18 January 2022

This is an Open Access article distributed under the terms of the Creative Commons Attribution License, which permits unrestricted use, distribution, and reproduction in any medium, provided the original work is properly cited. 